\title{
On the Principle and Scheme of Teaching Content Reform in the New Era
}

\author{
Dong-ju FANG \\ Department of Computer \\ Wuhan Polytechnic \\ Wuhan 430074, China \\ 867327860@qq.com
}

\begin{abstract}
In the new era, China, under the leadership of comrade Xi Jinping, needs to cultivate comprehensive talents that meet the needs of social development in the 21st century. It is urgent to reform the teaching content and curriculum system. Some concrete measures are given in this paper. For example, the teaching content reform and curriculum construction should be strengthened. The reform of teaching content and curriculum construction should follow the direction principle, scientific principle, adaptability principle and individuation principle. As long as the above points are achieved, colleges and universities will be able to cultivate versatile talents to meet the development needs of the new era where China is with the leadership of $\mathrm{Xi}$ Jinping.
\end{abstract}

Keywords-Comprehensive talents; Teaching content reform; reformation of course system; suggestion of implementation

\section{The NeCESSITY OF STRENGTHENING TEACHING CONTENT AND CURRICULUM CONSTRUCTION}

\section{A. To meet the needs of the international talent competition}

Facing the 21st century, all countries in the world, proceeding from their own national and national interests, have accelerated the economic development to enhance their overall national strength. Therefore, the economic strength competition, the comprehensive national strength competition is very intense. But the most important thing is the competition for talents, because only with talents can we master modern science and technology and modern scientific management. It is no exaggeration to say that whoever has the outstanding talents in the 21st century will win in the 21st century. Institutions of higher learning are important bases for training high-level talents for the 21st century. The teaching content and curriculum system of institutions of higher learning are basic projects that determine the quality of talents. Therefore, many countries that are developing the talent training plan, are studying and exploring the teaching contents and curriculum system of the 21st century, and pay attention to the training "general" international talent combining the basic, professional, valuable and internalized characteristics. To cultivate a large number of high-level talents in our country, intensified efforts must be made from the primary school, middle school, especially university teaching, and colleges should grab the education content, to adapt to the needs of the international talent competition[1].

\section{B. To meet the needs of the development of modern science and technology}

The teaching content and curriculum system of colleges and universities in mainland China were learned from the Soviet Union in the 1950s. Although there have been some changes over the years, they have not broken through the original framework. However, with the rapid development of modern science and technology and the vigorous rise of new scientific and technological revolution, traditional disciplines have been highly differentiated, and many interdisciplinary disciplines have intersected and penetrated each other. Neither teaching contents and curriculum system, nor the professional knowledge and the basic theory can adapt to this great change. At present, most of the basic courses in universities belong to the subject systems and contents before the 20th century, such as General Physics, Advanced Mathematics and General Chemistry, etc., which are based on Classical Physics, Calculus and Dalton's Chemical Atomic Theory[2]. Major theories since the 20th century have basically not been introduced into the basic courses, such as Relativity, Quantum Mechanics, System Theory, Nonlinear Theory, Quantum Chemistry, Molecular Biology and so on. Many science and engineering students in the School of Physics still have the concept of time and space stuck in the 19th century. Due to the slow update of college teaching content and the reform of middle school curriculum lagging behind, the teaching content of some basic courses is the same as that of middle school textbooks, which affects students' learning enthusiasm. Modern science and technology are developing, but the teaching content remains the same.

It has formed the contrast between the advanced scientific frontier theory and the obsolete basic course teaching content and system, which leads to the aging of the cultivated talent knowledge. As the basic course teaching content and system cannot meet the needs of modern social development and the requirements of talents in the 21st century, it must be updated and reformed.

\section{To meet the needs of the development of the market economy}

China's existing higher education structure, teaching content and curriculum system, the products of the planned economy for a long time, are born to cater to the development of the planned economy. As a planned economy is departmental economy and industrial economy, most colleges 
and universities run schools by departments or industries. Most of them are single-subject universities with relatively single teaching content and curriculum system. The professional knowledge students learn is suitable for the needs of their posts After the establishment of the market economy, the economic structure, industrial institutions and product structure change frequently, the old products are constantly eliminated, and the new products constantly appear, breaking the boundaries of sector economy and industry economy. It is far from enough for students to learn a certain major. In modern society, there are many new industries, new disciplines, and new specialties, and these disciplines intersect generating compound results. This requires that modern talents must have compound knowledge, certain adaptability and strain capacity and that students cultivated by colleges and universities must have solid foundation, broad knowledge, new major, high quality and strong ability. However, under the planned economy, colleges and universities generally attach importance to professional knowledge, but not to compound knowledge. Pay attention to the accumulation of knowledge, while neglecting the knowledge structure. Emphasize much more on the development of the structure and less on the development of personality. What's more, the physical quality outweighs the psychological quality. In order to change this situation, it is necessary to strengthen the construction and reform of college teaching content and curriculum system.

\section{To meet the needs of student employment}

Under the planned economy, college students are subject to "unified allocation", that is, unified enrollment, unified curriculum and unified schedule. Students have no freedom to choose courses or arrange their study schedule. This kind of practice is adapted to the needs of the planned economy, and the students have no complaints. Because the students are all unified by the state distribution after graduation, and are all candidates for the state cadres, they do not worry about finding a job; as the students receive the education in the university at public expense, they ought to obey national arrangement. Therefore, at that time, the teaching content and curriculum setting had no influence on the employment of students, and students did not pay much attention to it, so they followed the school's plan and arrangement. However, in the market economy, universities are no longer training only state cadres, but all kinds of talents and all levels of talents needed by society. On the other hand, college students are no longer studying at public expense. After graduation, they are no longer controlled by the state, but have independent choices of jobs. It is impossible for the state to implement a unified plan for the distribution of millions of college graduates. Starting from their own interests and economic benefits, employers will no longer accept graduates according to the plan, but choose graduates independently by meeting the demand and supply and making two-way choices. Therefore, college students are no longer required to learn what they want to learn. Instead, they should be able to independently choose majors, take elective courses and arrange the learning schedule according to social needs and personal specialties and interests. So, colleges and universities must change the past planned economy under the old teaching contents and curriculum system, establish the new content and system, in order to meet the different needs of different students, open a large number of elective courses, such as social needs of new courses, writing a new teaching material, the course system, credit system, the main minor system, such as small double degree. Only when students master broad and solid basic knowledge and establish reasonable knowledge structure based on social and market needs, can they have strong ability to respond to changes in industrial structure, employment structure and talent market.

\section{E. The need to change the current unreasonable course structure}

The planned economy is a sectoral economy and an industrial economy, which requires a large number of specialized talents to meet the needs of the department and industry. The curriculum and teaching contents of colleges and universities are also set according to the needs of the department and industry. As a result, there are many problems in the course structure and teaching contents of colleges and universities in China, such as too many class hours, too many weekly class hours, too many professional compulsory courses, obsolete teaching contents and unadaptable to the needs of modern social development.

\section{ThE BASIC PRINCIPLES OF THE CONSTRUCTION OF TEACHING CONTENT AND CURRICULUM SYSTEM}

\section{A. Directivity principle}

The teaching content and curriculum system are the main channels for schools to educate and impart knowledge to students, and they play an important role in the growth of students. Therefore, it is necessary to insist that education must serve the socialist construction, be combined with productive labor, and train builders and successors who develop morally, intellectually and physically in an all-round way. In terms of teaching arrangement and curriculum setting, attention should be paid to improving students' ideological and moral quality, strengthening political theory courses and ideological education courses, and arranging military training and public welfare labor into teaching plans as compulsory courses to comprehensively improve students' quality. There should be more time for students to participate in social practice, to increase knowledge, enhance ability, increase the contact with workers, peasants, soldiers and intellectuals, absorb nutrients, and promote their own development. To change the "teaching content and curriculum construction" is to impart professional knowledge to students not as a one-sided point of view, but as a part of the overall school education, and set up three days of moral, intellectual and physical education. Education is the focus of the school, including the cultivation of students' ideological and moral quality, cultural and knowledge quality, ability quality and physical and psychological quality. In today's world of fierce competition for talents, all countries attach great importance to the direction of education, and the ideological and moral education of students. For example, the education reform plan signed by President Bill Clinton in March 1994, Goals 2000: Educate America Act, stipulates that the education of promoting students' good moral character is an important part of the eight national education goals of the United States in 2000. Japan proposes that "moral education is 
the destiny of Japan in the 21st century. And three requirements are put forwarded on the quality of the talents: (1) good education and excellent character (2) to contribute to social development and improve welfare; (3) stay original.

\section{B. Scientific principle}

The teaching content and curriculum system should conform to the needs of subject development and talent training and a reasonable knowledge structure should be constructed. Some schools propose to optimize content, strengthen application, response to the Times. The optimized contents are as follows: keeping the original subject content unchanged, optimizing and selecting the lecture content, highlighting the key points and difficulties in the classroom teaching, emphasizing the ideas and methods to reconstruct the new knowledge structure of the subject course, so as to adapt to the development of the subject and the learning needs of students. "Strengthen the application, reflect the modern" mainly refers to that the curriculum should have practical and applied value, to reflect the latest development of modern science and technology results and information. When establishing the teaching content and curriculum system of a certain major, we should also consider the connection and sequence of knowledge and conform to the laws of education, including the law of knowledge dissemination, the law of teaching, the law of gradual progress, the law of individualized teaching and the law of students' physical and mental development. The core of the curriculum structure is the optimization of the combination of courses, the formation of the most scientific and reasonable knowledge system that is most conducive to the growth of talent.

\section{Adaptability principle}

The construction of teaching content and curriculum system should meet the needs of the development of modern society, the development of science and technology and the employment market. Many colleges and universities in mainland China have also taken some effective measures in this regard. For example, Wuhan University has made great efforts to dilute the professional boundary, optimize the course structure, reduce compulsory courses and increase the number of elective courses, reduce the proportion of compulsory courses for general majors to below $60 \%$ and increase the proportion of elective courses and designated elective courses to over $40 \%$. We believe that colleges and universities should pay attention to the transformation from narrow knowledge to compound knowledge, from the increase of knowledge to the optimization of knowledge structure, and from the inculcation of book knowledge to the development of students' ability in teaching and curriculum construction. In addition, it is necessary to strengthen the teaching and training of practical links and combine teaching, scientific research and production[3].

\section{Personalization principle}

The teaching content and curriculum should be diversified and personalized to meet the different needs of students and promote the full play of students' interests and specialties. As students have different foundation quality, and hobbies, so do the requirements for them. In teaching, we must teach according to one's aptitude. The following three points should be highlighted in curriculum construction. (1) Curriculum diversity. Schools should offer a large number of courses for students to choose, in addition to public basic courses and professional compulsory courses, so that students can choose other courses according to their needs. (2) Course hierarchy. That is to set up the same course with different levels for a subject. That is to say, carry out course with same basic content but different depth, different capacity, different characteristics, different number of hours and credits for different majors, and for different students. (3) Modularity of the course. A course is divided into several knowledge modules with different characteristics for students of different subjects, majors or hobbies. Peking University has rich experience in the construction of teaching content and curriculum system, and has achieved obvious results. They developed a strategy of "strengthening the foundation, downplaying the specialty, teaching students in accordance with their aptitude, and cultivating students in different levels". The specific measures are as follows: (1) Offering minor majors and second degree majors; (2) Offering liberal arts and science students to choose courses from each other, and requiring them to complete certain credits; (3) Students must take an art course; (4) Offering more than 20 public elective courses, including chaos and fractal, Beethoven special subject, environmental science, religion, etc.; (5) The experimental class of science is offered, and six compulsory basic courses of mathematics, science, chemistry, biology, geography and politics are arranged. The experimental class of arts strengthens the common foundation of humanities and social sciences in terms of curriculum arrangement, and also strengthens the course of advanced mathematics. (6) Create a strong campus cultural environment, such as holding various lectures, organizing more than 130 student societies, carrying out reading activities, and holding "environmental culture month", "cultural relic month", "legal culture month", "art and self-cultivation culture festival", "reading culture festival" as well as various literary and artistic competitions and performances[5].

\section{SUGGESTIONS ON THE IMPLEMENTATION OF CURRICULUM CONSTRUCTION}

After the discipline and specialty setting of a school are determined, it is necessary to construct the curriculum system of the discipline and specialty, that is, to construct the knowledge structure of the students of the specialty. The curriculum construction is directly related to the "what to teach and how to teach" of teachers and the "what to learn and how to learn" of students[4].

The main content of course construction includes course structure (system) construction, data material construction, teaching method and teaching method construction. There are five types of courses in terms of curriculum structure.

(1) Public compulsory courses. The courses must be taken on the basis of public courses, include political theory courses, ideological education courses, foreign languages, computers, physical education, military training and public welfare labor, accounting for $20 \%$ of the total credits. 
(2) Professional required courses. Students of a certain major must learn professional basic courses and professional courses. Professional basic courses account for $30 \%$ of the total credits, and professional courses account for $15 \%$ of the total credits.

(3) Limit elective courses. That is to expand the scope of public compulsory courses and professional compulsory courses, add a number of courses, so that students according to their needs and interests, choose a number of courses, among which public basic courses account for $5 \%$ of the total credit, professional basic courses account for $5 \%$, professional courses account for $5 \%$.

(4) Elective course of cultural literacy. It's actually a restricted elective. There are eight categories of this course: humanities, social sciences, natural sciences, political thought, art, language, sports and health, and others. About 8 12 courses are offered in each class, and students can choose any course in each class, accounting for $10 \%$ of the total credits. From the practice of some colleges and universities, the structure of each class is as follows.

Humanities: including College Chinese, Applied Writing, Appreciation of Chinese and Foreign Literature, Appreciation and Creation of Classical Poetry, Ancient Chinese Etiquette Culture, Tourism Etiquette, American Social Culture, Western Philosophy, Introduction to Western Culture, Journalism and Communication, etc.

Social science: including Introduction to Economics, Introduction to Management, Introduction to Law, Public Relations, Social Survey and Statistical Analysis, Principles of Political Science, Youth Science, Psychological Counseling, Sociology, and Introduction to Social Science, Appreciation of Famous Works, etc.

Natural science: including Advanced Mathematics, General Physics, Chemistry, General Biology, Astrophysics, Introduction to Natural Science, Science of Science, History of Modern Science and Technology, Introduction to Environmental Science, Cartographic Basis, Office Automation, Scientific Research Methodology, etc.

Ideological and political studies: including Study of Marxist Classics, Study of the National History of the People's Republic of China, Comparative Study of Socialism and Capitalism, Study of Modern Historical Figures, Study of Contemporary Cross-strait Relations, Party Constitution and Basic Knowledge of the Party, International Affairs, etc.

Language: including Japanese, Russian, German, and French and so on.

Art: including Music Foundation and Appreciation, European Music Appreciation, Chinese Folk Music, Dance and Appreciation, Drama and Appreciation, Symphony Appreciation, Vocal Music Enhancement Class, Film Art, Calligraphy Foundation, Sketch Painting and so on.

Sports health: including College Students Health, Martial Arts Qigong Health, Aerobics, Chess, Intelligence Games and so on.
Others: Studies, Photography, Higher Education, Public Speaking and Eloquence, Advertising, etc.

(5) Optional course. The optional course chosen independently by the students accounts for $10 \%$ of the total credits, and it is part of our high school reconstruction in the teaching reform of curriculum structure, it has the following characteristics: (1) Expand the students' knowledge, because the professional basic course and public foundation account for $35 \%$ of the total credits, and culture diathesis $10 \%$, and any electives up to 55\%; (2) The compulsory courses of professional basic courses and professional courses account for $45 \%$ of the total credits, and another $10 \%$ are optional courses for students, changing the immobilization of professional courses; (3) In terms of the overall structure, the credit of public basic courses is the highest, followed by professional basic courses, and the class hours of professional courses are compressed to the third place, which meets the requirements of thick foundation, wide knowledge and professional knowledge. (5) To set up optional courses, to provide students with the opportunity to choose courses freely, this is conducive to meet the individual needs of learning knowledge. Different types of schools and different majors can also proceed from their own actual situation, and formulate the curriculum structure and teaching system for the needs of the 21st century.

\section{CONCLUSION}

In order to adapt to the international talent competition, the reform of teaching content and curriculum construction should be strengthened. The reform of teaching content and curriculum construction should meet the direction principle, scientific principle, adaptability principle and individuation principle. As long as the above points are achieved, colleges and universities will be able to cultivate comprehensive talents that meet the needs of the national development in the new era with the leadership of Comrade Xi Jinping.

\section{REFERENCES}

[1] XU Jing-yin, XUE Jing. How to optimize curriculum system and strengthen connotation construction in vocational colleges [J]. China adult education, 2015, (4):85-87.

[2] WANG Xiao-wei, LIU Bing. On the curriculum reform of entrepreneurship education for college students [J]. Modern economic information, 2016, (21) DAI Chun-ping. A new probe into the concept of education socialization in college students' ideological politics[J].Journal of Wuhan university of science and technology.2008(1):83.

[3] LIU Yang. Reform of college innovation and entrepreneurship curriculum in the context of entrepreneurship and innovation [J]. Journal of EZhou University, 2017, (2):76-78

[4] XIAO Chi-ping, ZHANG Xiao-qing. On the whole-process construction of college students' employment guidance curriculum system [J]. Heilongjiang higher education research, 2007, Yang caiyun. Application of action-oriented teaching method in Chinese teaching in secondary vocational schools [D]. Central China normal university, 2012

[5] FANG Ru-jian, ZHU Xi-fang, WU Ting. On the construction of college innovation and entrepreneurship education system [J]. Journal of Changzhou institute of technology (social science edition) 